\title{
Non-ferrous Metal Recycling and Waste Treatment by Smelting or Refining Companies
}

\author{
Kanehiro MONZEN
}

\begin{abstract}
Resources recycling is necessary for the sustainable society in the 21 century. Smelting or refining companies in Japan have treated non-ferrous metal scraps for many years and commenced wastes treatments about three decades ago. Their technologies and facilities are available for treatments of wastes bearing a few of non-ferrous metals because they have many experiences of extracting dilute non-ferrous metals in mineral resources.

Virgin non-ferrous metals and their scraps are used for wires, batteries, platings or secondary raw materials of virgin non-ferrous metals etc.. Recycled non-ferrous metals, i.e. virgin metals refined from scraps account for $10 \%$ to $45 \%$ of total each new non-ferrous metal refined in Japan. It is estimated that a content of a non-ferrous metal in secondary raw materials treated in smelters depends on a price of the virgin nonferrous metal.

And, the amount of wastes treatments and non-ferrous metal recoveries from wastes in 2000 increased compared with 1999.
\end{abstract}

\section{1. 緒言}

20 世紀における人間社会の福祉と成長は, 大量の生産 と消費に根ざすものであり, その結果, 大量の廃棄物を 生み出したといわれている。

しかしながら，人類が，21 世紀も持続的な発展を遂げ るためには，資源やエネルギーを効率的に利用する努力 を払いながら，循環型社会に変えていく必要があろう。

非鉄製錬業界は，銅・鉛・亜鉛・貴金属に代表される 非鉄金属素材を製造している。非鉄金属素材の原料は鉱 石であるが，スクラップや廃棄物からも非鉄金属を回収 しており，その数量も漸増している。

元来非鉄製錬技術は，目的金属と微量に共存する有用 金属を抽出・分離する技術であり, 抽出する金属は上述 のほかニッケル・アンチモン・カドミウムなど 30 種類 にも及んでいる。このため, 最近ではこれらの蓄積技術・ 設備を利用して, 一般には処理困難とされる廃棄物, 例 えば，製鋼電炬ダスト，鉛蓄電池，エレクトロニクス部

* 日本鉱業協会 技術部

平成 13 年 12 月 28 日受理
品・部材，電池などから有用金属を回収している。

ここでは, 非鉄製錬業界の環境事業 $=$ 廃棄物処理・リ サイクル事業の規模の概要を, ベース・メタル（銅・鉛・ 亜鉛）を中心に紹介する。

\section{2. ベースメタルのマテリアル・フロー}

非鉄製鍊業界で生産された電気銅, 電気鉛, 電気要鉛, 蒸留亜鉛（当業界で生産されたこれらを新地金と呼ぶこ ととする）などが，どのように使われ，どのように当業 界に戻ってくるかを概観するために，これらのマテリア ル・フローを, 2000 年の統計值 ${ }^{1}$ を例にとって見てみる ことにする。

\section{1 銅のマテリアル・フロー}

第 1 表に示すように，国内に流通する銅地金は，電気 銅（銅純度 $99.9 \%$ 以上の電気銅），銅の故又はくず（銅 純度 $97 \%$ 以上のスクラップ), 銅合金の故またはくず(銅 純度 $50 \%$ 以上のスクラップ) の三種類に分けて統計が取 られている。

電気銅の内需は 1,347 チトンであり，電線製造に 62 $\%$ ，伸銅品製造に $35 \%$ が消費される。使用済みになった 電線, 伸銅品は回収され, 銅の故またはくず, 銅合金の 故またはくずとなる。(これらもまた，加工され，使用さ

Vol. 49, No. 1 ('02-春) 
第 1 表 非鉄金属地金の国内需要量

(2000 年, チトン)

\begin{tabular}{|c|c|c|c|c|c|c|c|c|c|c|c|}
\hline 用途 & 電気銅 & $\begin{array}{l}\text { 銅の故 } \\
\text { 又くず }\end{array}$ & $\begin{array}{c}\text { 銅合金 } \\
\text { の故又 } \\
\text { くず }\end{array}$ & 用途 & 電気鉛 & 再生鉛 & $\begin{array}{l}\text { 鉛の故 } \\
\text { 又くず }\end{array}$ & 用途 & $\begin{array}{l}\text { 亜鉛 } \\
\text { 新地金 }\end{array}$ & $\begin{array}{l}\text { 再生 } \\
\text { 亜鉛 }\end{array}$ & 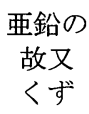 \\
\hline 電線 & 844 & 221 & - & 鉛管板 & 3 & 1 & - & めつき & 415 & 39 & 12 \\
\hline 伸銅品 & 474 & 476 & 628 & 蓄電池 & 186 & 33 & 11 & 伸銅品 & 75 & 17 & - \\
\hline 銅合金-鋳物 & - & - & - & 電線被覆 & 5 & - & - & $\begin{array}{c}\text { 亜鈆ダイカス } \\
\text { 卜 }\end{array}$ & 54 & 5 & 4 \\
\hline 製錬 & - & - & 149 & 無機薬品 & 33 & 5 & 2 & 無機薬品 & 36 & 10 & 19 \\
\hline \multirow[t]{4}{*}{ その他 } & 29 & 67 & 140 & $\begin{array}{l}\text { はんだ・ } \\
\text { 鉛合金塊 }\end{array}$ & 7 & 2 & - & 亜鉛板 & 5 & - & 1 \\
\hline & & & & 製錬 & - & - & 138 & 製鍊 & - & - & 2 \\
\hline & & & & 再生 & 1 & 7 & 85 & 再生 & - & - & - \\
\hline & & & & その他 & 16 & 2 & 2 & その他 & 29 & 1 & 49 \\
\hline 合計 & 1,347 & 765 & 918 & 合計 & 251 & 50 & 237 & 合計 & 668 & 74 & 88 \\
\hline
\end{tabular}

（注）「故」とは非鉄金属の圧延工場などで発生する，比較的大きな塊のくず。「くず」とは非鉄金属の二次加工工場 などで発生する, 打抜きくず, 切削くずなどの比較的形の小さなくず。鉛, 亜鉛の「故又はくず」には, 涬（非鉄 金属を溶解した際の, 溶融体の表面の浮き涬）も含む。なお，各項目を四捨五入しているため合計值とは合わない ことがある。

れ, 使用済みとなった後, 再び「故」として回収される。 銅の故またはくずの内需は 765 千トンであり, 伸銅品 製造に $62 \%$ ，電線製造に $29 \%$ が使われる。

銅合金の故またはくずの内需は, 918 千トンであり， 伸銅品製造に $68 \%$ ，銅合金・鋳物に約 6\%（2000 年の 統計では「その他」に集計されているものと思われるの で, 1999 年の使用量から推定)，銅製錬原料として $16 \%$ が使用される。

この様にマテリアル・フローを見てみると, 高純度の うちは主として電線製造に用いられ, 繰り返し使用して いく中で純度が低下して, 伸銅品製造, 銅合金・鋳物, 銅製鍊原料へとカスケード・リサイクルされていること が理解できよう。

\section{2 鉛のマテリアル・フロー}

国内に流通する鉛地金は, 電気鉛（鉛純度 $99.95 \%$ 以 上のもので, 主として鉱石起因の電気鉛), 再生鉛（鉛純 度 $90 \%$ 以上のもの), 鉛の故またはくず（鉛純度 $50 \%$ 以 上のもの）に分けて統計が取られている。

電気鉛の内需は 251 チトンで, 蓄電池製造に $74 \%$, 無 機薬品製造に $13 \%$ が消費される。使用済みになった蓄電 池などは，鉛の故またはくずとして回収され，製品製造 や再生鉛 (鉛スクラップを融解し, 浮㳯を取った後鋳込 み，製品製造の原料とするもの)の原料，あるいは鉛製 鍊原料となる。

再生鉛の内需は 50 千トンで，蓄電池製造に $66 \%$ ，無 機薬品製造に $10 \%$ ，再生鉛製造に $14 \%$ が消費される。

鉛の故またはくずの内需は 237 チトンであり, 蓄電池 製造に $5 \%$ ，再生鉛製造に $36 \%$ ，鉛製錬原料として $58 \%$ が消費される。
銅のマテリアル・フローとの大きな違いは，銅は中間 再生をすることなく純度が低下するまで「使い回し」さ れるが，鉛は「再生」というリサイクル業が存在する。 これは，鉛は銅よりも酸化されやすいことに起因するも のと考えられる。したがって，鉛は「使い回し」される ことは少なく，回収された「故」の多くは鉛製錬に戻さ れることになる。

\section{3 亜鉛のマテリアル・フロー}

国内で流通する亜鉛地金は, 亜鉛新地金（亜鉛純度 98 \%以上のもの, 電気覀鉛と蒸留亜鉛の 2 種類があるので, 「亜鉛新地金」と表現する), 再生亜鉛（亜鉛純度 $90 \%$ 以 上のもの)，亜鉛の故またはくず（亜鉛純度 $50 \%$ 以上 90 \%未満のもの）の三種類に分けて統計が取られている。

亜鉛新地金の内需は, 614 千トンであり，めつき用に $68 \%$ ，伸銅品製造に $12 \% ，$ ダイカスト製造に $9 \%$ ，無機 薬品製造に $6 \%$ が消費される。

使用済みになったダイカストなどは，亜鉛の故または くずとして回収され, 製品製造や再生亜鉛(亜鉛スクラッ プを融解し，浮涬を取った後鋳込み，製品製造の原料と するもの）の原料，あるいは亜鉛製錬原料となる。

再生亜鉛の内需は 74 千トンであり, めっき用に $58 \%$, 伸銅品製造に $23 \%$ ，無機薬品製造に $14 \%$ が消費される。

亜鉛の故またはくずの内需は 88 千トンであり, めつ き用に $14 \%$ ，無機薬品製造に $22 \%$ ，再生亜鉛製造に約 60\%（2000 年の統計では「その他」に集計されている と思われるので, 1999 年の使用量から推定）が消費さ れ，亜鉛製錬原料としては僅か $2 \%$ である。

マテリアル・フローの形態としては, 鉛に似ているが, 鉛に比して製錬原料となるもののが少ないのは，統計対 




第 1 図電気銅生産量と二次原料使用の状況

象外の「亜鉛の故」が多いためである。（亜鉛製鍊用原料 となるスクラップの中心は製鋼ダストであるが，これは 亜鉛品位が低いために「亜鉛の故」とはならない。）

\section{3. 非鉄製鍊業における第一義的リサイクルの状況}

最近「リサイクル」という言葉はたびたび使われるが, 非鉄製錬業界では, 従来からのリサイクルすなわちスク ラップ等を原料として非鉄金属新地金を生産するリサイ クルと, 廃棄物から非鉄金属を回収するリサイクルとが ある。ここでは従来型の, スクラップを原料とするリサ イクルの状況を見ることにする。

新地金生産量と, スクラップなどの二次原料の使用状 況は金属種によりかなり異なるので,それぞれについて, 過去約 10 年間の変化を統計值 ${ }^{2)}$ から見てみる。

\section{1 銅の状況}

第 1 図に電気銅生産量と二次原料使用の状況を示す。 電気銅生産量は漸増しているが, 二次原料出電気銅の生 産量に大きな増加は認められず，全生産量に対する二次 原料出電気銅の比率は $10 \%$ 程度で減少傾向にある。

二次原料は, 故銅, 統計の対象にならないスクラップ, 製鍊所繰返物（非鉄製鍊業内におけるリサイクルと理解 できよう）からなるが，その使用量に大きな変化は見ら れない。しかしながら，二次原料に対する製錬用故銅量 の比率は僅かではあるが増加が認められる。

二次原料使用量に対する二次原料出電気銅の生産量の 比は，二次原料のおおよその銅品位を示すものと考えら れるが, この推定品位は $55 \sim 70 \%$ 程度であり, 漸増傾

Vol. 49, No. 1 ('02- 春)
向にある。

\section{2 鉛の状況}

第 2 図に電気鉛生産量と二次原料使用の状況を示す。 電気鉛の生産量は, 徐々に減少してきているが, 二次原 料出電気鉛量は増加しており，全生産量に対するに二次 原料出電気鉛の比率は $20 \%$ 程度から $45 \%$ 近くまで増加 している。

また, 二次原料の使用量も増えており, 製鍊用故鉛量, 二次原料に対する製鍊用故鉛量の比率も 1995 年から急 激に増えている。この急激な変化は, 前年に（社）電池 工業会が「鉛リサイクルプログラム」(使用済み蓄電池か ら鉛をリサイクルする費用を蓄電池メーカーが負担し， 蓄電池のリサイクルを推進しようというもの)を発表し， 当業界の受入れ故鉛量が増大したことによるものであ る。これに伴い, 二次原料中の鉛の推定品位は, 30 〜 $45 \%$ 程度であったものが， $65 \%$ 程度にまで上昇してい る。

\section{3 亜鉛の状況}

第 3 図に亜鉛新地金と二次原料使用の状況を示す。亜 鉛新地金の生産量は, 漸减傾向にあるが, 二次原料出亜 鉛新地金量は微増しており, 全生産量に対するに二次原 料出亜鉛新地金の比率は $10 \%$ 程度から $20 \%$ 近くまで増 加している。

また，二次原料の使用量も増加しているが，製錬用故 亜鈶使用量は减少傾向にある。二次原料中の推定亜鉛品 位は 50 〜 60\%の間で上昇傾向にある。 


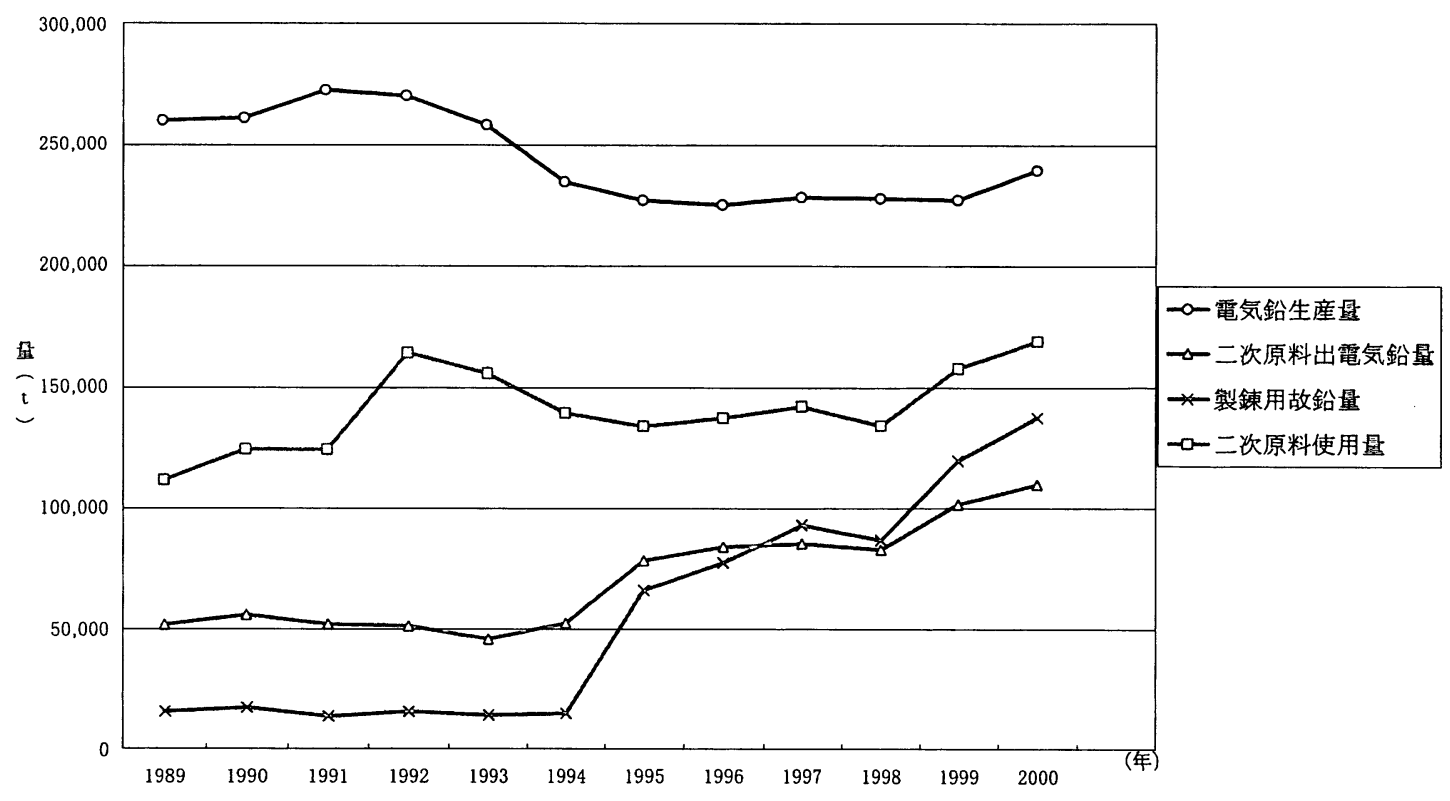

第 2 図 電気鉛生産量と二次原料使用の状況

\section{4 二次原料品位に対する一考察}

上述のように，二次原料中のベースメタルの推定品位 は増加傾向にある。最近の循環型社会形成の気運からす れば, 低品位のものの集荷が進展すると考えられるので, 二次原料中の非鉄金属品位は下がるはずであるが, 結果 は逆である。
一方, 過去約 10 年間の地金の国際価格を見ると, 銅, 鉛については高騰した時期もあったが総体としては下落 傾向，亜鉛については小幅な上下はあったが総じて減少 傾向にあった。国内価格 ${ }^{3)}$ は，為替の影響を受けて，さ らに下落傾向を示している。

第 4 図に二次原料推定品位と新地金国内価格との関係



第 3 図 亜鉛新地金生産量と二次原料使用の状況 


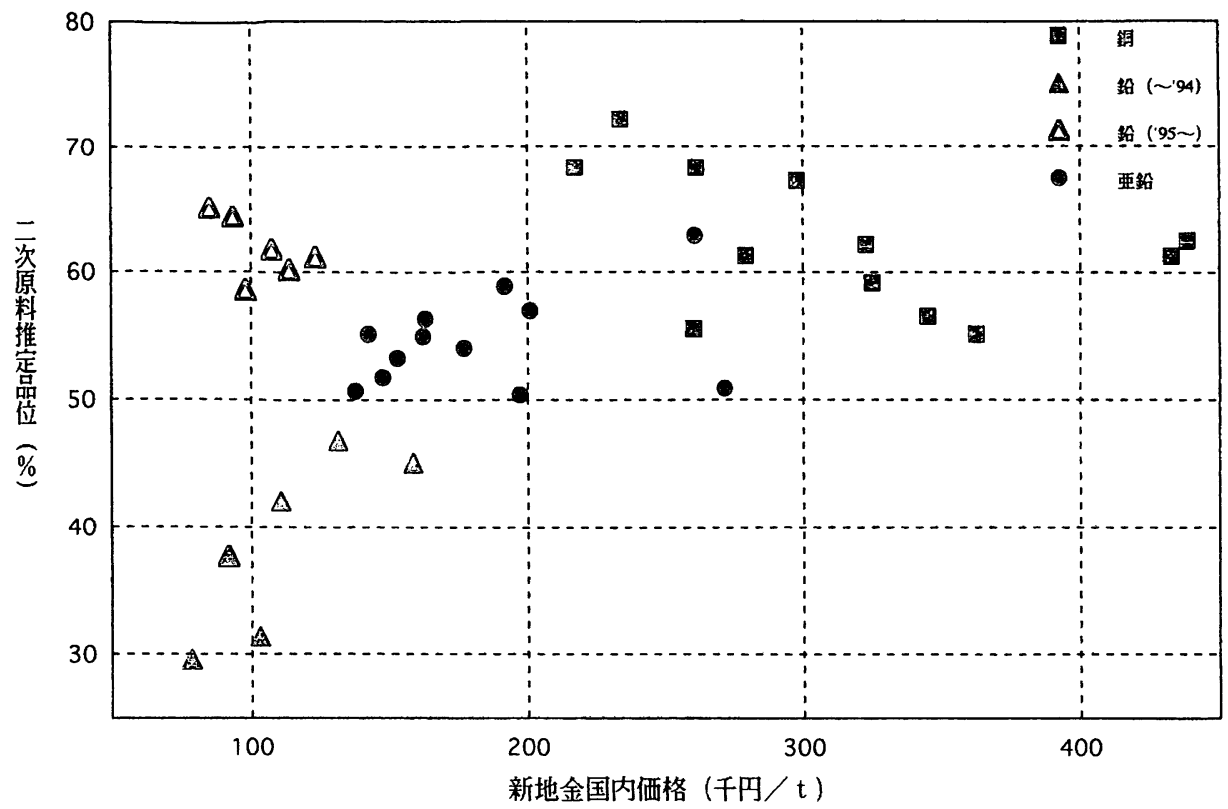

第 4 図 二次原料推定品位と新地金国内価格の関係

を示すが，両者に明確な相関は認められないものの，銅 については, 価格の下落とともに推定品位は上昇傾向に ある（注）すすなわち，事業として集荷・処理を行なうた めには, 単位あたり重量の価値に下限があるということ を意味する。このようなことは風評として過去から言わ れており，それを単純に裏付ける結果となっている。「地 球環境」といえども経済原則で動くということを示して いるのかもしれない。

（注）鉛については，1995 年以前と以降では大きく変 化している。これには, 前述の「鉿リサイクルプログラ ム」が影響しているものと思われる。このプログラムが できる直前は, 鉛新地金の価格の低さをスケール・メリッ トで補填する，採算性の悪い集荷・処理が行なわれてい たことをうかがわせる。

亜鉛については，二次原料に占める製鋼ダストの比率 が大きく，これが逆有償（処理費用を受領する）である ために, 二次原料推定品位は亜鉛新地金価格の影響を比 較的受けにくいものと推定される。

\section{4. 非鉄製鍊業における第二義的リサイクルの状況}

日本鉱業協会では, 会員企業の廃棄物処理・リサイク ル事業の実績を集計4) しているので，ここに 2000 年度 の実績を紹介する。

\section{1 事業規模}

単独ベースの売上高は 812 億円で, 総売上高に占める 割合は $4.5 \%$ である。子会社を含めた連結べースの売上 高は， 850 億円である。

\section{2 処理 · 回収実績}

第 2 表に処理・回収の実績を示す。従来型のリサイク ル原料（いわゆるスクラップで，原料として購入したも の）の処理量は約 435 千トンで，1999 年度に比べて約 46 千トン増えている。これは，貴金属㵏・廃電子部材 / 部品が約 41 千トン減少したにもかかわらず，銅・亜鉛 の涬類が約 83 千トン増えたことによる。

第 1 図から第 3 図の，2000 年における二次原料使用 量の合計は約 578 千トンである。「年」と「年度」とい う集計時期の違いはあるが，リサイクル原料の処理実績 と 150 千トン近くの差がある。これは，リサイクル原料 には，後述の廃棄物処理から産出される非鉄二次原料と 製鍊繰返物を含まないことによる。

廃棄物（処理費を受領するもの）の処理量は約 1,001 千トンで, 1999 年度に比べて約 146 千トン増え, 漸く 百万トンの大台を越えた。廃酸・廃アルカリが約 103 千 トン, 污泥・廃油が約 89 千トンと大幅に増え, シュレッ ダーダストを中心とする廃プラスティックが約 21 千ト ン増えている。一方，亜鉛涬を中心とする金属くずが約 35 千トン, 電炉ダスト以外のばいじんが約 38 千トン减 少している。当業界の廃棄物処理は焼却・溶融を主とす るものであり, 全国での産業廃棄物の焼却量が 18,000干 トンといわれていることからすれば，5\%のシェアを持 つことになる。

二次原料出新地金などの再資源化量は約 360 千トン で, 1999 年度に比べ 1,300 トンの微増にとどまってい る。銅の再資源化量は約 9 千トン増えているが，鉛は約 
第 2 表 非鉄製錬業界の廃棄物処理・リサイクルの実績（2000 年度）

A. リサイクル原料と処理量

\begin{tabular}{|c|c|}
\hline リサイクル原料 & 量（t） \\
\hline 故銅 & 112,704 \\
\hline 銅涬 & 85,991 \\
\hline 廃蓄電池 & 124,223 \\
\hline 鉛涬 & 22,606 \\
\hline 覀鉛涬 & 35,681 \\
\hline 貴金属涬 & 35,681 \\
\hline 廃感光剤 & 3,960 \\
\hline 廃液 & 680 \\
\hline 廃電子部材／部品 & 10,334 \\
\hline その他 & 5,520 \\
\hline 合計 & 434,981 \\
\hline
\end{tabular}

17 千トン减少している。このようにベースメタルは減少 しているが，それ以外のものの再資源化量の増大によっ て昨年度並みの量を維持している。

\section{5. 結言}

当業界の廃棄物中間処理事業は, 他の廃棄物焼却事業 者が減容化を中心にしている中で, 廃棄物の持つエネル ギーの回収・廃棄物処理への利用を行なうとともに，有 用物の回収・スラグの有効利用などを行っており，より 一層循環型社会の構築に寄与しているものと自負してい る。

21 世紀は「環境の世紀」とうたわれ，循環型社会を目 指して, 循環型社会形成推進基本法をはじめ, 種々のリ サイクル法が制定された。今後も新しい法律が制定され ることであろう。

循環型社会を構築するために必要なアクションは,リ デュース,リュース，リサイクルと言われている。今後
C. 再資源化量

\begin{tabular}{|c|c|}
\hline 再資源化品 & 量（t） \\
\hline 銅 & 146,018 \\
\hline 鉛 & 109,504 \\
\hline 亜鉛 & 110,041 \\
\hline 金 & 39 \\
\hline 銀 & 834 \\
\hline ニッケル & 270 \\
\hline 錫 & 200 \\
\hline カドミウム & 655 \\
\hline 水銀 - 化合物 & 50 \\
\hline フェライト原料 & 2,500 \\
\hline ガラスカレット & 1,600 \\
\hline 化成品 & 6,121 \\
\hline 金属原料 & 2,060 \\
\hline 合計 & 379,892 \\
\hline
\end{tabular}

$(4,900)$

208,182

$(201,000)$

1,200

3,850

$1,001,208$
ともリサイクルの最終の担い手「カスケード・アンカー」 として，新世紀の地球環境に貢献していきたいと考えて いる。

宣伝めいていて恐縮ではあるが，参考資料として，非 鉄製鍊業界の事業所別廃棄物処理・リサイクル事業の現 状と環境事業連絡先一覧表を添付させていただいた。何 かのお役に立てば幸甚である。

\section{参 考 文 献}

1）経済産業省経済産業政策局調査統計部編；「平成 12 年 資源統計年報」より作成

2）通商産業省通商産業大臣官房調查統計部編，経済産 業省経済産業政策局調査統計部編; 「平成元年～平成 12 年 資源統計年報」より作成

3）（財）金属鉱山会，日本鉱業協会編；「鉱山」vol. 51 No. $81998 / 10$ p. $280 \sim 285$, vol. 54 No. $12001 / 1$ p 概 $12 \sim 13$ より作成

4）（財）金属鉱山会，日本鉱業協会編；「鉱山」vol. 54 No. 12 2001/12 に掲載予定 
（参考資料）事業所別廃棄物処理リサイクル事業の現状

\begin{tabular}{|c|c|c|c|c|c|c|c|}
\hline 事業場名 & 処理品目 & リサイクル対象 & 年間処 & 実績（t） & 年間処理能力 & $(\mathrm{t})$ & 備考 \\
\hline $\begin{array}{c}\text { 住友金属鉣山㑣 } \\
\text { 播磨事業所 }\end{array}$ & a)スラッジ類 & a) 垔鉛·鉛 & a) & 800 & a) & 800 & \\
\hline 住友金属鉱山㑣 & a)銅系スクラップ & a) 銅 & a) & 19,000 & a) & 30,000 & \\
\hline 別子事業所 & b) 鉄鋼電炉ダスト & b) 亜鉛·鉛 · 鉄 & b) & 75,000 & b) & 120,000 & \\
\hline \multirow[t]{3}{*}{$\begin{array}{l}\text { 中外鉱業(㑣) } \\
\text { 持越工場 }\end{array}$} & a) 貴金属涬 & $\begin{array}{l}\text { a) 金・銀・パラジウム・ } \\
\text { 銅 }\end{array}$ & a) & 3,120 & a) & 5,000 & \\
\hline & b) 廃感光材 & b)銀 & b) & 3,960 & b) & 7,000 & \\
\hline & c) 廃液 & c) 金 · 銀 & c) & 680 & c) & 2,000 & \\
\hline \multirow[t]{6}{*}{$\begin{array}{l}\text { 東邦亜鉛㑣 } \\
\text { 小名浜製錬所 }\end{array}$} & a)廃ニカド電池 & $\begin{array}{l}\text { a) カドミウム・ニッケ } \\
\text { ル }\end{array}$ & a) & 1,500 & a) & 3,000 & \\
\hline & b) 廃硫酸 & b) 硫酸 & b) & 3,900 & b) & 20,000 & \\
\hline & c）製鋼ダスト & c) 亜鉛 & c) & 60,000 & c) & 70,000 & \\
\hline & d)污泥 & d) - & d) & 4,000 & & & \\
\hline & e) 廃アルカリ & e) - & e) & 700 & & & \\
\hline & f) 廃油 & f) - & f) & 1,900 & & & \\
\hline 東邦亜鉛(㑣) & a) 廃硫酸 & a) 硫酸 & a) & 100 & a) & 2,000 & \\
\hline 安中製錬所 & b)使用済電池 & $\begin{array}{l}\text { b) 亜鉛・カドニウム・ } \\
\text { ニッケル }\end{array}$ & b) & 1,000 & b) & 2,000 & \\
\hline \multirow[t]{3}{*}{$\begin{array}{l}\text { 東邦亜鉛㑣 } \\
\text { 契島製錬所 }\end{array}$} & $\begin{array}{l}\text { a) バッテリースクラッ } \\
\quad \text { プ }\end{array}$ & a)鉛 & a) & 55,000 & a) & 80,000 & \\
\hline & b) 鉛涬類 & b) 鉛 & b) & 5,000 & b) & 80,000 & \\
\hline & c) 廃硫酸 & c) 硫酸 & c) & 1,300 & & & \\
\hline \multirow[t]{6}{*}{ 同和クリーンテック樕 } & a)エッチング廃液 & a) 銅 & a) & 10 & - 焼却施設 & & \\
\hline & b) プリント基板 & b)銅 & b) & 400 & - 中和施設 & 88,000 & \\
\hline & & & & & & 30,000 & \\
\hline & c) 大型鉛蓄電池 & c) 鉛 & c) & 0 & - 固化施設 & & \\
\hline & & & & & & 57,600 & \\
\hline & d) その他廃金物 & d) - & d) & 89,523 & & & \\
\hline 小坂製鍊㑣 & a) 故銅 & a) 銅 & a) & 8,330 & a) & 15,000 & \\
\hline \multirow[t]{4}{*}{ 小坂鉱山 } & b) 銅涬 & b)銅, 他 & b) & 8,930 & b) & 15,000 & \\
\hline & c)廃バッテリー & c)鉛 & c) & 4,830 & c) & 10,000 & \\
\hline & d)鉛涬 & d) 鉛 & d) & 1,860 & d) & 5,000 & \\
\hline & e) 廃基板類, 他 & e) 銅, 他 & e) & 1,500 & e) & 4,000 & \\
\hline $\begin{array}{l}\text { 樕日本ピージーエム } \\
\text { 小坂工場 }\end{array}$ & a) 廃触媒他 & $\begin{array}{c}\text { a) プラチナ・パラジウ } \\
\text { ム・ロジウム }\end{array}$ & a) & 5,000 & a) & 10,000 & \\
\hline 花岡鉱業(侏) & a) 土壤（洗浄） & a) 鉛 & a) & 10,300 & ·土袞洗浄設備 & & \\
\hline \multirow[t]{3}{*}{ 花岡鉣山 } & b) 廃 OA 機器等 & b) 銅 - 鉄他 & b) & 22 & & 240,000 & \\
\hline & c）金属くず & c) - & c) & 53 & & & \\
\hline & d) 産業廃棄物 & d) 埋立処分 & d) & 128,280 & & & \\
\hline 日本パール侏 & a) 産業廃棄物 & （一部熱回収） & a) & 52,093 & - 焼却施設 & 63,000 & \\
\hline 同和鉱業(㑣) & a) 産業廃棄物 & （一部熱エネルギー） & a) & 139,479 & - 焼却施設 & & \\
\hline 岡山クリーンワークス & & & & & & 144,000 & \\
\hline 光和精鉣㑣 & a) 産業廃棄物 & a) 非鉄製鍊原料 & a) & 196,686 & ・硫黄燃焼炉 & & \\
\hline \multirow{9}{*}{ 戸畑製造所 } & & （亜鉛・鉛） & & & & 43,000 & \\
\hline & & & & & ・流動はい㮱炉 & 156,000 & \\
\hline & & & & & ・ペレットキルン & ン焼却施 & \\
\hline & & & & & 設 & & \\
\hline & & & & & & 33,000 & \\
\hline & & & & & ・産廃キルン焼去 & 却施設 & \\
\hline & & & & & & 60,000 & \\
\hline & & & & & ・廃液焼却施設 & & \\
\hline & & & & & & 18,000 & \\
\hline
\end{tabular}


（参考資料）事業所別廃棄物処理リサイクル事業の現状

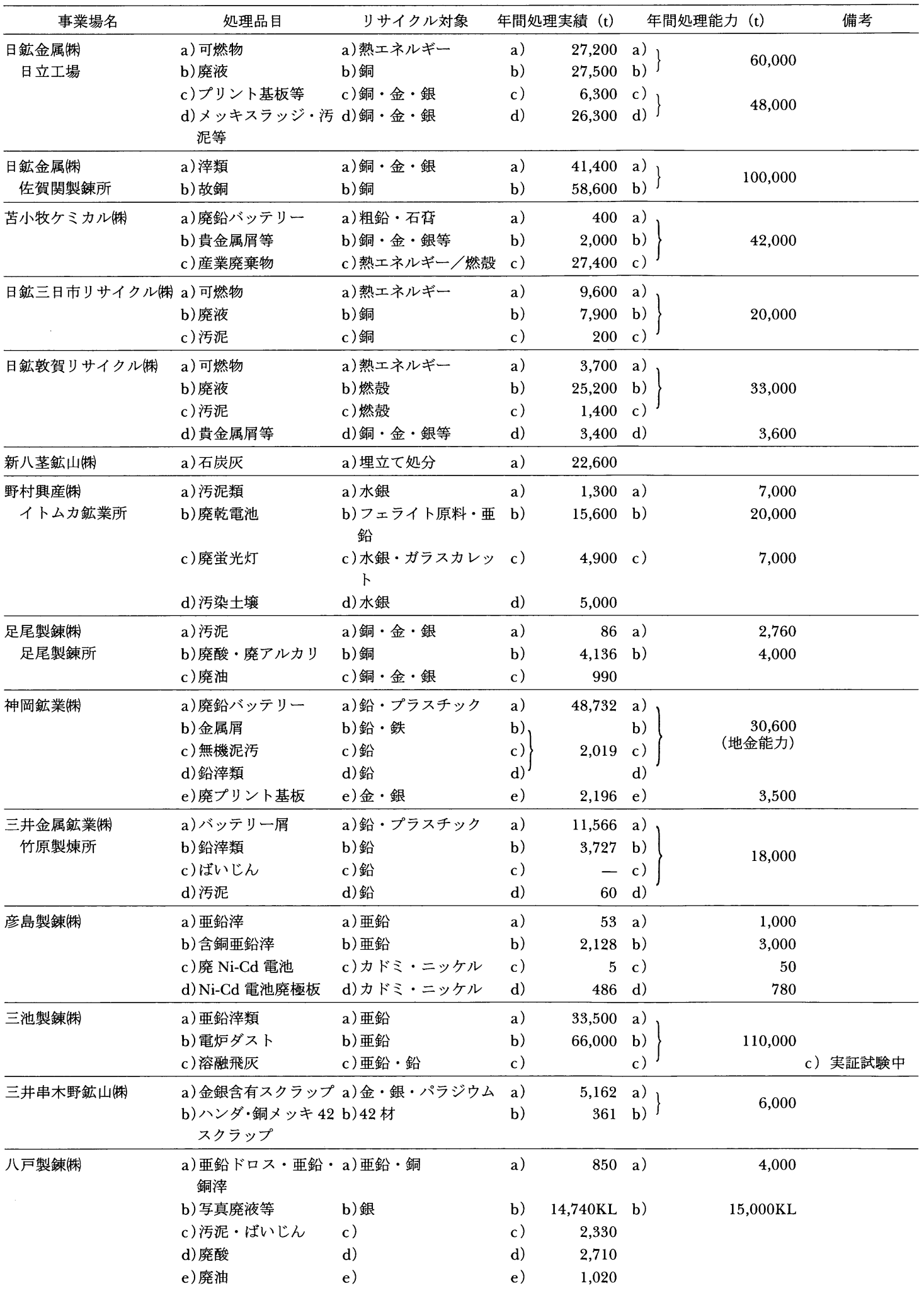


（参考資料）事業所別廃棄物処理リサイクル事業の現状

\begin{tabular}{|c|c|c|c|c|c|c|c|}
\hline 事業場名 & 処理品目 & リサイクル対象 & 年間処 & 理実績（t） & & 里能力 $(t)$ & 備考 \\
\hline $\begin{array}{l}\text { 日比共同製錬㑣 } \\
\text { 玉野製錬所 }\end{array}$ & $\begin{array}{l}\text { a) 鉱涬類 } \\
\text { b) 銅涬類 } \\
\text { c)故銅 }\end{array}$ & $\begin{array}{l}\text { a)銅 } \\
\text { b)銅 } \\
\text { c)銅 }\end{array}$ & $\begin{array}{l}\text { a) } \\
\text { b) } \\
\text { c) }\end{array}$ & $\begin{array}{l}4,661 \\
9,774\end{array}$ & $\left.\begin{array}{l}\text { a) } \\
\text { b) } \\
\text { c) }\end{array}\right\}$ & $\begin{array}{r}13,560 \\
(\text { 銅処理能力) }\end{array}$ & \\
\hline 日本亜鉛 & a) 焼却灰 & a) 埋立処分 & a) & $18,747 \mathrm{~m}^{3}$ & & & $\begin{array}{r}\text { 坑内埋立可能量 } \\
300,000 \mathrm{~m}^{3} \\
\end{array}$ \\
\hline $\begin{array}{l}\text { 三菱マテリアル㑣 } \\
\text { 直島製錬所 } \\
\end{array}$ & $\begin{array}{l}\text { a）故銅・銅さい・金銀 } \\
\text { さい }\end{array}$ & $\begin{array}{l}\text { a) 銅・金・銀・白金・パ } \\
\text { ラジウム }\end{array}$ & a) & 52,000 & a) & 52,000 & \\
\hline $\begin{array}{l}\text { 三菱マテリアル株 } \\
\text { 生野事業所 }\end{array}$ & a)錫さい & a) 錫 & a) & 810 & a) & 900 & \\
\hline 細倉製錬(侏) & $\begin{array}{l}\text { a) 廃鉛バッテリー } \\
\text { b)鉛さい }\end{array}$ & $\begin{array}{l}\text { a) 鉛・プラスチック } \\
\text { b)鉛・銅・金・銀 }\end{array}$ & $\begin{array}{l}\text { a) } \\
\text { b) }\end{array}$ & $\begin{array}{l}31,000 \\
10,000 \\
\end{array}$ & $\begin{array}{l}\text { a) } \\
\text { b) }\end{array}$ & $\begin{array}{l}31,000 \\
12,000 \\
\end{array}$ & \\
\hline $\begin{array}{l}\text { 小名浜製錬侏 } \\
\text { 小名浜製錬所 }\end{array}$ & $\begin{array}{l}\text { a) 廃タイヤ } \\
\text { b) シュレッダーダス } \\
\quad \text { ト } \\
\text { c)故銅 }\end{array}$ & $\begin{array}{l}\text { a) 熱エネルギー } \\
\text { b) 熱エネルギー・銅 } \\
\text { c)銅 }\end{array}$ & $\begin{array}{l}\text { a) } \\
\text { b) } \\
\text { c) }\end{array}$ & $\begin{array}{r}900 \\
56,000 \\
16,000\end{array}$ & $\begin{array}{l}\text { a) } \\
\text { b) }\end{array}$ & $\begin{array}{r}6,000 \\
90,000 \\
16,000\end{array}$ & \\
\hline
\end{tabular}

（参考資料）環境事業連絡先一覧

\begin{tabular}{|c|c|c|c|}
\hline 会社名 & 空口 & 所在地 & 電話 \\
\hline 住友金属鉱山侏 & エネルギー・環境事業部 & $\begin{array}{l}105-8716 \\
\text { 東京都港区新橋 5-11-3 }\end{array}$ & $03-3436-795503-3436-7738$ \\
\hline 中外鉣業(株) & R\&D 事業部 & $\begin{array}{l}\text { 100-0005 } \\
\quad \text { 東京都千代田区丸の内 1-5-1 }\end{array}$ & 03-3201-1541 03-3201-5019 \\
\hline 東邦亜鉛(侏) & 環境・リサイクル事業部 & $\begin{array}{l}\text { 103-8437 } \\
\text { 東京都中央区日本橋本町 1-6-1 }\end{array}$ & $03-3272-565703-3271-0070$ \\
\hline 同和鉱業(株) & リサイクル事業部 & $\begin{array}{l}\text { 100-8282 } \\
\text { 東京都千代田区丸の内 1-8-2 }\end{array}$ & $03-3201-125503-3201-1258$ \\
\hline 日鉱金属株) & 環境リサイクル事業部 & $\begin{array}{l}\text { 105-0001 } \\
\text { 東京都港区虎ノ門 2-10-1 }\end{array}$ & $03-5573-730603-5573-7592$ \\
\hline 日鉄鉱業(株) & 機械・環境営業部 & $\begin{array}{l}\text { 110-0005 } \\
\text { 東京都江東区亀戸 2-26-11 }\end{array}$ & $03-5627-351003-5627-3516$ \\
\hline 野村興産侏 & 業務部 & $\begin{array}{l}\text { 103-0012 } \\
\text { 東京都中央区日本橋堀留町 2-1-3 }\end{array}$ & $03-5695-253303-5695-2540$ \\
\hline 古河機械金属(侏) & 金属技術部 & $\begin{array}{l}100-8370 \\
\quad \text { 東京都千代田区丸の内 2-6-1 }\end{array}$ & $03-3212-283003-3212-6558$ \\
\hline 三井金属鉱業(侏) & 金属事業本部 & $\begin{array}{l}\text { 145-0032 } \\
\text { 東京都品川区大崎 1-11-1 }\end{array}$ & 03-5437-8061 03-5437-8073 \\
\hline \multicolumn{2}{|c|}{ 三菱マテリアル侏環境リサイクル事業センター } & $\begin{array}{l}\text { 112-0002 } \\
\text { 東京都文京区小石川 1-3-25 }\end{array}$ & 03-5800-9310 03-5800-9372 \\
\hline
\end{tabular}

